\title{
WALK THIS WAY: Fitbit and Other Kinds of Walking in Palestine
}

\author{
ANNE MENELEY \\ Trent University \\ (iD) https:/ / orcid.org/0000-0002-5627-6124
}

The Fitbit, a wearable activity tracker first introduced in 2008, is but one of the newly ubiquitous digital self-tracking devices. (Their acronym, DSTD, makes them sound like diseases acquired without forethought for lingering regret!) According to some analysts (e.g., Sanders 2017, 36), DSTDs are instrumental to "biopower and patriarchy" in the neoliberal era. Readers can decide for themselves if the story of how I got a Fitbit falls under the rubric of biopower and patriarchy: my eighty-five-year-old father, on his doctor's advice, began to count his steps with a pedometer, a primitive DSTD. He emailed me a daily account of his stepstaunting me, as a lazy academic, with 8,200 one day, 9,500 the next, which in the competitive habitus of our family I took as a challenge. I got a Fitbit and proceeded to email him back with accounts of my daily steps. My friends and colleagues sometimes appear a bit shocked that I wanted to compete with my aging father. And imagine my horror when I read a book chapter entitled "Foucault's Fitbit" (Whitson 2014), which also opens with a father-child walking competition, although Luka, the child in this vignette, is a two-year-old tot, not a professor of anthropology. Sensing that there was more going on here than an instantiation of "biopower and patriarchy, I was inspired to explore how new forms of surveillance may enter into our lives in ways that are neither universal nor predictable. 
Walking is of course known to every culture, but only recently has walking become envisioned as an activity to be divided into steps, quantified, and - importantly - recorded by technologies attached to the body. A classically Maussian, nondiscursive technique of the body (see Mauss 1973) has become a discursive technique in its cyborgian manifestation: walking while recording has turned into a topic for discussion, a point of comparison and surveillance of the kind that concerns academic observers (Whitson 2014; Lupton 2016; Nafus 2016; Neff and Nafus 2016). These critical scholars have a point about self-tracking: the frightening possibilities of people reduced to quantifications (heart rates, glucose levels, blood pressure, calories consumed, pounds gained). Some commentators worry that employers may encourage their employees to wear self-tracking devices and then use the information thereby garnered to approve or deny health-care coverage. In societies without universal health care, it could have serious implications if the sedentary sick were blamed (or shamed) for their own condition (cf. Moore and Robinson 2016 on neo-Taylorism).

As a university professor who complains about the relentless quantification of our academic production, our audit culture, if you will, I was shocked at my susceptibility to the Fitbit. I found it strangely compelling to have my footsteps recorded, and felt quite perturbed when I forgot my Fitbit on a day when I had walked a lot. On one level, of course, one does know that exercise is exercise, recorded or not, but still. The writer and humorist David Sedaris (2014) has perhaps best captured the speed and lunacy of the quick descent into autocompetition: "At the end of my first sixty-thousand-step day, I staggered home with my flashlight knowing that I'd advance to sixty-five thousand, and that there will be no end to it until my feet snap off at the ankles.... Why is it some people can manage a thing like a Fitbit, while others go off the rails and allow it to rule, and perhaps even ruin, their lives?"

While I don't think I have gone off the rails and I still have my feet, events like forgetting keys or books upstairs or my son constantly borrowing my car suddenly have a fringe benefit: more steps! Even those too cool to wear a Fitbit may fall prey to the addiction of counting, as they can record their steps on their cell phones. I have had colleagues who refuse to go for a walk if they have forgotten their cell phones and ones who have returned home to get their Fitbits so they wouldn't "waste" a day of not counting their steps. Gina Neff and Dawn Nafus (2016) also had interlocutors who reported distress without their Fitbits, as their emotions became imbricated with the technology. "The data," Neff and Nafus $(2016,76)$ argue, "become a 'prosthetic of feeling,' something to help us sense our bodies or the world 
around us." Theories of the gaming world might hold some answers to the Fitbit's persuasiveness: while the telic version of Fitbit walking is the goal of exercise, the autotelic goals that we set for ourselves may lead to our "personal satisfaction" (Sicart 2014, 238). While some, like Sedaris, engage in brutal self-competition, others grant the Fitbit a kind of nonhuman agency, making of it a technological superego, like an informant of mine who sighs when her Fitbit gently buzzes at ten minutes to every hour. "It's step o'clock!" she exclaims, or: "Damn! My FitBitch tells me I have to take another 250 steps." My nephew, an employee of a multinational oil company that offered compensation $(\$ 3,000)$ for adherence to a Fitbit program, outsourced his exercise by giving his Fitbit to his girlfriend as she left to go on a walk even as he lay on the couch chatting with me. Some people are very creative at retrofitting the Fitbit exercise ideology to induce playful competition between themselves and others. One colleague proposed a "Walk with Wine" program for those who do not want exercise to cut into the cocktail hour, encouraging his Facebook friends to strap on a Fitbit, fill a reusuable cup with a crisp white wine, and walk!

This last example came across my screen when I was conducting field research in Jerusalem in the spring of 2017. Jerusalem is a city people have imagined, flocked to, and walked in for centuries. Walking is itself particularly important to Christian pilgrims to the Holy Land: many of them feel inspired to walk in the footsteps of Christ. My first visit to Jerusalem more than a decade ago coincided with Easter weekend: I was nearly trampled by fervent Christian pilgrims memorializing Jesus on his way to crucifixion by walking the Stations of the Cross. This walking in the steps of a martyr forms an integral part of their imagination of, and engagement with, a city that for many represents a moving spiritual destination. Walking in Jerusalem might be considered a religious technique of the body, a means of constituting a pious self by walking the sacred routes. I myself have experienced a different kind of walk there: political pilgrimages, too, employ walking as a means of tracing embodied contemporary sufferings in Jerusalem, particularly the ongoing persecution of Palestinians under continuing Israeli occupation. These walks often trace former sites of Palestinian presence: as we walk, we learn about how Jerusalem, sacred to all the monotheistic traditions, is scarred by the eviction of Palestinian families from their homes and the construction of Israeli-only neighborhoods. While not religious in the same sense as other tours, most participants find these walks unsettling yet personally transformative, much as I did (see Meneley 2014). A key practice of early Zionists was walking through a very differently imagined Zionist homeland, as I discuss below (see Benevisti 2000; Stein 2009). All these kinds of walking shape our understandings of ourselves and the stories 
we tell about ourselves, but the Fitbit seems to shape a different self: a capturable, knowable, commensurable, quantified one.

Aside from my playful competition with my father, I decided to see how the technology of the Fitbit would shape my experience of, and stories about, Jerusalem. Technological accompaniments to walking are not themselves new. Thomas Hobbes had an inkwell in his walking stick to record his thoughts; the compass has enabled wilderness walkers to find their way; and music gadgets and mobile phones form part of an assemblage of what Mizuko Ito, Daisuke Okabe, and Misa Matsuda (2005) call "personal, portable, pedestrian” technologies (2005). But the current DSTDs are central to a different imagining of bodies in affluent societies. According to Rebecca Solnit (2000, 263), after we stop using our bodies for functional reasons or manual labor, our bodies become "pets" that we train and coddle. There is a moral element here, too: by taking care of our bodies through exercise, including walking, we inculcate ourselves as healthy, moral citizens. The Fitbit technology allows us the wherewithal to provide the material sign, in Max Weber's sense, of our healthy piety: the good walking self is the recorded walking self. Jamie Sherman (2016, 30), drawing on Walter Benjamin's notion of the aura rather than the expected figure of the flaneur, notes the contemporary co-occurrence of self-quantification and the selfie, indexing different modes of understanding the self.

One day, I took my Fitbit and my body as healthy moral pet-self on an iteration of the Ramparts'Walk in Jerusalem, a walk now controlled by the Israeli tourism board; 18 (around \$5) allows one to walk the high walls surrounding Jerusalem's Old City. Placards mark famous historical moments: the Byzantine era here, the Crusader period there, and the Ottoman period further on. At the end of my walk, I realized that I had paid little attention to the famous views of wider Jerusalem afforded by the high walls, or to the bustling daily activities of the Old City below. Why? I had been preoccupied with recording the number of my steps at each placard. The bright sun had made it difficult to see my Fitbit screen, and between fumbling with my Fitbit, notebook, and cell phone, my attention was exclusively taken up with recording my self. I could have been anywhere. But I then took a very pious selfie, finally acknowledging Jerusalem, or at least a Jerusalem with me in it, and sent it to my father as part of our competition. In implicit acknowledgment of Jerusalem's fame in the monotheistic tradition, he replied: "Hi Anne, Holy Steps - you are looking great! I got my hearing aids adjusted and picked up some stuff from the drugstore, some steps but not up to your mileage, Love Dad.” My curated pet-self noted in my field notes that I had done 3,778 steps from Jaffa Gate 
to Al Aqsa mosque - surely one of the least interesting and consequential bits of information about one of the world's most beautiful and contested places!

I suspect I am not the only one who feels unsettled by the potential of the focus on the quantified self to the exclusion of place, especially in a place as politically, culturally, and religiously significant as Jerusalem - since the Fitbit does not really care where you take these steps. Over the course of "earning" accomplishments on the Fitbit, the device sends out notes congratulating the user on "earning your Nile badge" or your "Serengeti badge," acknowledging that one has walked the length of the Nile or the Serengeti in miles. Where one has actually walked these miles remains immaterial.

Some try to combine a pious pilgrimage self with a pious healthy step-counting self. American parishioners from Iowa use their Fitbits to count their steps, while also trying to imagine the pilgrimage of Mary carrying the baby Jesus more than two thousand years ago in the Holy Land: two pieties, of health and religion, here become intertwined as individuals walk (Arland-Fye 2016). Another example was a kind elderly guest at St. George's Cathedral Guesthouse, who after thanking his Palestinian guide for his moving tour of political disruptions in East Jerusalem, showed him how many steps the tour had taken. His guide looked bemused.

I myself received the same bemused look when I returned to Palestine in October 2017 to participate in the olive harvest as part of my ongoing research on agro-resistance. While the Palestinians I talked to about the Fitbit thought it was hilarious, if somewhat foolish, they did not actually record their steps or see much point in beginning to do so. Because I wrecked my Fitbit charger by flinging it into a bag as I rushed out olive picking, I cannot share my actual step count on a Jerusalem tour I took that began with the Palestinian neighborhood of Silwan, whose residents have been displaced by the City of David archaeological dig, part of a long-term project to settle Jewish families in East Jerusalem (see Paz 2014). Our guide, Daoud, a lifelong resident of the Old City, had once been arrested by the Israelis for doing tours like the one in which my fellow olive pickers and I were participating: one that explained in detail the Israeli usurpation of Palestinian neighborhoods not only with archaeological digs and settlements but also by forbidding Palestinian residents to restore their own houses. My step count seemed superfluous when witnessing the settler takeover of Palestinian space, but as my Fitbit walking proved a productive way to elicit commentary on other forms of walking in Palestine, I managed to work up enough anthropological hubris to ask Daoud if he knew of a place where I could get a Fitbit charger. We asked around in the Muslim Quarter, but all we received were quizzical looks and suggestions that I go to Israeli West Jerusalem, where I was 
told to use my phone to record my steps like everyone else did, waving me back toward East Jerusalem, saying that no one in Israel used the Fitbit brand.

Marcel Mauss's concept of techniques of the body explores how the universal practice of walking is performed differently in different cultural and historical moments. Although classic works of ethnomethodology (e.g., Ryave and Schenken 1974) ignored these wider cultural contexts, there is an enduring relevance in their brilliant eye for detail around the embodied ways people conduct themselves and interpret the actions of others through the minutiae of their bodily comportment. More recently, the burgeoning self-quantification literature (Lupton 2016; Nafus 2016; Neff and Nafus 2016; Ruckenstein and Schüll 2017; Schüll 2017) exhibits a tension between the potential for self-surveillance to gain positive control over oneself (women co-opting information and tactics of reproductive control for their own personal and political projects) and a concern over the use of self-surveillance data for the benefit of others (doctors, corporations, governments) or the potential of this data to have unintended consequences when it is revealed. Strava, a website and mobile app that allows users to share and compete with others through logging their athletic activity, published a heat map representing the activities of its users in November 2017. ${ }^{1}$ The Fitbit is so common in affluent capitals that the use patterns show up on the map as a blob, but in places where few people wear them, the use patterns mean that their locations are quickly revealed. For instance, the U.S. Army has handed out Fitbits to encourage its personnel to get more exercise, but as they jogged around the perimeters of their army bases in Syria, the secret locations of these bases were inadvertently revealed on the Strava map, as an analyst with the Institute for United Conflict Analysts discovered (Hern 2018).

\section{WHO GETS TO TREAT THE BODY AS A PET?}

The first line of Sarah Pink and Vaike Fors's $(2017,375)$ article on DSTDs in Australia and Sweden notes how portable self-tracking devices have become so embedded in the everyday lives of people in affluent societies that they begin to shape how people imagine themselves and their social and physical geographies in profound ways. Sometimes states find self-tracking devices useful for inculcating a desire for health in their citizen population. In Singapore, the government has a National Step Challenge encouraging Fitbit use (and even pays for Fitbits for its citizens). New mobile technologies such as the Fitbit afford a quantification of the act of walking that seems to correspond to what is sometimes called the neoliberal self, a self no longer based on the restrained tension between private and public but on a fundamentally competitive sense of self as a list of achievements (Urciuoli 2008; Gershon 
2016) — an outlook evident in the competition on the Strava website. Barbara Ehrenreich (2018), a searing critic of wellness culture in the neoliberal age, notes how the self-tracking of physical exercise can be perceived as the ultimate achievement of control over the self, which represents one of the most common illusions of modern life. My own experience demonstrates how persuasive it is in my own contemporary cultural and historical context to use self-surveillance for self-improvement projects or to subvert the self-surveillance technology. My father and I supposedly subvert the technology of self-surveillance with the overt purpose of improving our health in an age of sedentarism, engaging instead in playful competition. In affluent societies self-tracking can be perceived as a fully achievable right and a moral duty, or else as a form of play, but in other contexts it might constitute luxury, both in terms of the expense of the technological accoutrements and in terms of time. The luxury of self-surveillance for the sake of wellness and achievement is not equally available to all. Further, self-tracking can prove irrelevant or even dangerous in other places.

\section{WALKING WHILE PALESTINIAN}

Although my efforts to investigate Fitbit walking received no small amount of teasing from my Palestinian interlocutors, they also elicited conversations about the renewed interest in different kinds of walking in East Jerusalem and the West Bank. The kind of self-knowledge generated through Fitbit walking not only differs from other forms of walking in Palestine but also erases a key difference for determining how one can walk there: who you are and what you look like. In the occupied West Bank and in East Jerusalem where I conducted my field research, Palestinians are always assumed to be security threats who must be controlled; Israeli other-surveillance is built on a "framework in which Palestinians are categorically suspect" (Tawil-Souri 2016, 58). This is part of Palestinian contemporary quotidian reality, which shapes how they can and cannot walk. I am inspired here by Amahl Bishara's (2015) notion of "driving while Palestinian," which riffs on American politics around "driving while black," where one's phenotypical presence suffices to arouse the suspicion of law enforcement. Also central here is Garnette Cadogan's (2016) essay "Walking While Black," which describes the implications of one's phenotype for walking in particular spaces. He compares walking while black in Jamaica (where the majority of the population is black) to walking while black in the United States (where people of African descent represent a visible minority often viewed as threatening). Cadogan therefore draws our attention to a very different project of self-surveillance for black men walking in the United States as they try to avoid arousing suspicion or arrest, a project that offers valuable insights for walking in Palestine. Palestinians, 
especially young males, must also subject themselves to self-surveillance for their health. But it is not so much self-surveillance for the achievement of personal fitness goals but rather self-surveillance to avoid getting shot, harassed, or arrested while walking from one place to another. In this sense, Palestinians, too, are preoccupied with their bodies, but the concern is much more existential: being preoccupied about no longer inhabiting one's body at all (death) or no longer inhabiting it in the same way (injury as a result of being shot). This form of close self-surveillance requires much more attention than offloading the counting of one's steps to a mobile device strapped to one's wrist. Cadogan offers insightful reflections on how one manages one's phenotype with dress and bodily comportment, including voice modulation, speed, and gesticulation, to avoid arousing suspicion or arrest. His description evokes Suad Amiry's (2010, 122-25) telling account of how young Palestinian men attempting to sneak into Israel in search of work don sunglasses, manipulate their hairstyles, and roll up their shirt sleeves and pant legs to emulate, at least in their minds, young Israeli male fashion to avoid attracting the attention of the army or police. As I show in what follows, young Palestinian men walk in an entirely different manner outside of these contexts of other-surveillance.

Palestinian interest in Fitbit-type self-surveillance pales in comparison to the attention that they must pay, whether they like it or not, to other-surveillance, which constitutes a constant and oppressive part of their existence in a landscape scarred by what critics call an "apartheid wall" and the ubiquitous surveillance towers that punctuate it. Helga Tawil-Souri's $(2016,58)$ analysis of the "surveillance sublime" traces the contemporary surveillance practices of the Israeli state back to the British Mandate period with its population lists, land surveys, tax lists, and maps, detailing water sources, roads, and even tribal rivalries. For both, surveillance tactics have intricately entwined with military strategies. ${ }^{2}$ In the abstract, the modern surveillance of the population might be construed as both caring and controlling, but in the occupied territories, it is the security of Israelis, not of Palestinians, that is of concern. Despite the proliferation of high-tech surveillance tactics like closed-circuit television cameras and drones, the Israeli state achieves control of the population primarily through low-tech means: along with the much-photographed Wall, the checkpoint makes for the emblematic physical blockade where self- and other-surveillance takes place. At this point, one might almost refer to a checkpoint genre, one that permeates film (Elia Suleiman's Divine Intervention) and art (Sharif Waked's Chic Point: Fashion for Israeli Checkpoints), to mention only two examples.

Checkpoints are infrastructures of control imbricated in the structures of feeling of the occupied West Bank: Peteet $(2007,38)$ describes the feeling of "anx- 
ious anticipation" and "unpredictability" generated by the checkpoint as a central node in the "calibrated chaos" of the occupation. Lila Abu-Lughod (2007, 102) notes how walking through the checkpoints during her father's final illness and funeral became her heart-rending, embodied way of feeling her father's stories: "I had heard my father's stories all my life, but it is different to walk, orphaned, through a hot dusty checkpoint dragging your suitcases because they won't allow any Palestinian vehicles to cross. It is different to be held up by arrogant soldiers with reflective sunglasses and burnished muscles who willfully delay you." Rema Hammami (2004, 2010, 2015, 2018) turns the quotidian checkpoint traumas that she, her students, and her colleagues experience on their way to Bir Zeit University into data in her ongoing anthropology of that particular barrier; she describes her use of this daily trauma as an anthropological weapon of the weak.

Even as Israel is known for its lucrative high-tech surveillance technology exports, the low-tech tactics of ID cards and permits, so memorably described in the poet Mahmud Darwish's “Identity Card,” hold immense significance and power. Inexpensive, fragile material objects, they and their colors resemble the checkpoints in their ability to determine possibilities of movement or lack thereof (Tawil-Souri 2010, 2011, 2016, 2017; see also Berda 2018, 107-124 on the "effective inefficiency" of the Israeli permit regime). Palestinians of course also engage in other-surveillance as they learn to read and manage the fear of the armed soldiers and settlers in the West Bank to maintain their own safety. Over the years, I've heard many versions of the quip "better hope the soldier got laid last night!", which reflects the knowledge that sometimes what triggers the young soldiers might be personal and go well beyond perceived Palestinian provocation. A soldier's contentment, over which Palestinians have little control, may affect the treatment they receive as they try to get on with their daily lives (see Tawil-Souri 2011, 11-12). As checkpoints continually disrupt and "steal" time (Peteet 2017, 139-68), the temporality and footsteps recorded by the Fitbit take on a different valence.

\section{OF FITBITS AND OTHER MOBILITY TECHNOLOGIES}

In 2016, the Jerusalem Quarterly had to expand a summer special issue on surveillance titled "We Are Watching You" to a winter issue titled "We Are Still Watching You," indicating the density of historical and contemporary surveillance in Palestine. Even as being documented and surveilled is unwanted, avoided, or feared, the Israeli ID cards and permits are necessary for movement through checkpoints. ${ }^{3}$ While there is no indication that walking through a checkpoint is designed to encourage Palestinian physical fitness, one of the few times I have come across refer- 
ence to the use of DSTDs in Palestine is in a checkpoint walk in the documentary A Slim Peace (2007). This documentary chronicles what I consider one of the most unsettling peace initiatives ever: getting Israeli and Palestinian women together to “diet for peace." As well as counting calories and lost pounds, participants count their steps with pedometers. ${ }^{4}$ The documentary follows one Palestinian participant as she makes the humiliating walk through the checkpoint, showing her permit with her special permission to enter Jerusalem to the Israeli soldier. We then see her witty cursing at the weight-loss meeting where, after being publicly weighed, she is supposed to recount her steps only to discover that her pedometer has malfunctioned: the only positive thing about the time-wasting, boring, and stressful ordeal of going through the Qalandiya checkpoint is that it requires steps that can be counted and then proudly recounted in the meetings that form part of the weight-loss competition - which, while it certainly did not lead to peace, at least allowed a few Palestinian women access to their beloved capital (Meneley 2016). It also gives us an opportunity to reflect on who gets to treat their body as a pet and their steps as an achievement toward a moral, pious (slim) self, versus who can only see recorded steps as the single positive aspect of humiliating institutions of control over the everyday movement of Palestinian bodies.

Another example of how technology designed to shape movement ends up taking a particular form when it lands in Jerusalem comes in the form of a different technology for "doing walking," as ethnomethodologists refer to it: Pokémon GO. Fabio Cristiano and Emilio Distretti (2017) examine how the universally popular game of Pokémon GO operates in a Jerusalem informed exclusively by Israeli imaginings of it. Pokémon GO is a game played on one's cell phone: it is touted as a means of propelling children usually stuck in front of computers out into the world, providing them with a "healthy game experience" (Cristiano and Distretti 2017, 131), since playing involves walking in the outside world. It seems a benevolent game, completely in keeping with the pieties of DSTDs: inculcating a moral (healthy) pious self by cultivating a moral (healthy) pious self in one's children. The augmented reality of the game translates certain kinds of landmarks in the real world into parallel landmarks in the virtual space of the game, so-called Pokestops, from which players not only orient themselves but also derive Poké Balls, the tools one needs to capture animated Pokémon monsters. But as Cristiano and Distretti (2017) point out in their study of how the abstract overlaid space of Pokémon GO operates in the concrete occupation space of East Jerusalem, the game in fact reinforces the Israeli state's notion of a unified Jerusalem without a Palestinian presence: there are no Palestinian landmarks and hence no Pokestops, no Poké Balls, and no Pokémons 
to be captured. The vibrant, crowded, historically rich East Jerusalem appears empty in the game. Cristiano and Distretti $(2017,131)$ argue that Pokémon GO "provides players with a depopulated and neutralized image of East Jerusalem, empty of the fetishes of the occupation." The game thus "loses its innocence in the very moment that the act of playing becomes one of preserving the status quo, built according to and through lines of separation imposed by Israel's order." This trenchant critique demonstrates how a game for children ends up constituting yet another way in which Israel tries to erase Palestinian presence in Jerusalem.

\section{WALKING TO STAY PUT}

Erasing or displacing Palestinian presence and stopping movement in the Palestinian territories is the way Israelis establish continual sovereign moments, proving who is ultimately in charge of the territory (see Tawil-Souri 2017,400). Julie Peteet's (2017) rich ethnography describes the myriad ways of restricting Palestinian movement in occupied East Jerusalem and the West Bank, documenting the negative effects of stasis, being stuck, obstructed, and delayed against one's will. Peteet describes those who cannot face moving because they are sick, weak, or, heartbreakingly, afraid of peeing themselves at a checkpoint. While many Israeli infrastructures prevent easy everyday movement (Cohen and Gordon 2018, 199), their overarching goal seems to be to achieve the ultimate mobility: for Palestinians to leave the Holy Land, never to return. The writer Erskine Childers referred to this goal as the early Zionist hope, the "wordless wish" (Abu-Lughod 2007, 88) that Palestinians would simply disappear. But Palestinians want to stay on their own land. Jess Bier (2017, 54) discusses the positive aspect of stasis, "the ability to remain in place." Stasis in this reclaimed sense does not denote the negative sense of stagnation or obstruction, but the positive value (and virtue) of not moving. Steadfastness (sumood), a "nationalistically inflected form of stoicism" (Allen 2008, 456), refers to this positive (Palestinian-initiated) staying put, which infuses many strategies of resistance to the occupier's attempts to disconnect Palestinians from their land by thwarting movement. My seemingly silly Fitbit competition with my father, ironically, inspired me to pay more attention to various forms of walking, allowing me to attend to the importance of movement even as the literature on Palestine focuses on overwhelmingly on the infrastructures of control and stoppage. Walking (mobility) becomes increasingly employed as a strategy for stasis and for attempts to reconnect with the land at a moment when Palestinian access to it is increasingly threatened. Nadera Shalhoub-Kervorkian (2016), reflecting on going to work in East Jerusalem in times of duress, provides a moving example of the stasis power of quotidian walking: 
At about seven in the morning, and like every other day, we are in the streets of the Old City, each heading to her or his destination. I walk in silence, to voice our right to normalcy, togetherness, and safety in our streets. As we walk, we salute and smile at each other, speak in low voices, sometimes whisper, and interact only when necessary. But mostly we remain silent and try to move normally through the streets packed with Israeli military equipment, armed settlers, and army and security personnel. Under such conditions, our morning ritual is imbued with fierceness as we Palestinians reclaim our hijacked spaces by simply walking in them. (emphasis added)

Walking lies at the center of Raja Shehadeh's (2007) moving memoir Palestinian Walks. Foregrounded here is not the number of steps Shehadeh takes, but the number of places in which Shehadeh and other Palestinians can no longer walk on their own land, as Israeli settlements, Israeli-only highways, and the Wall expand and Israeli stipulations on where Palestinians cannot go increase. In The Old Ways, the chronicler of walking Robert Macfarlane (2012) relays his hosting of Shehadeh on a walk in his home in England, where the Palestinian conveys his longing for a less-militarized future in Palestine. Macfarlane then writes of a return visit he paid to Shehadeh in Ramallah, describing the unexpected emotional force of constraints on movement and the dangers that Palestinians face with more nonchalance than he can initially muster. Shehadeh directs Macfarlane's attention to settlements on the hilltop, identifiable by their red roofs; the latter's attention is drawn to the surveillance effect of the settlements themselves, their capacity to facilitate the settlers' observing outward and downward, which, as the Israeli architect Eyal Weizman (2007) has pointed out, forms part of the design itself. Capturing the embodied sensation of many of us when we look up at this surveillance landscape for the first time, Macfarlane $(2012,217)$ reports: "I felt very nervous."

Walter Benjamin's $(2003,36)$ flâneur concerned himself with "botanizing on the asphalt," and he would have plenty to botanize in the contemporary Holy Land: these days, the Land of Milk and Honey looks more like the Land of Milk and Asphalt, between the Wall and the proliferation of settler-only highways. Macfarlane, however, includes the geological substrate in accounts of his walks by naming his chapters in The Old Ways after geological formations. His chapter on Palestine is titled "Limestone," the rock formation whose bubbly, distinctive strength holds up most of Palestine's terraces and their famous olive groves. Shehadeh tells him that the long-lived olive trees, emblems of one of the oldest human-nonhuman collaborative relationships, provide horticultural evidence of a longstanding Palestinian 
presence on the land. Macfarlane $(2012,217)$ also notes the Israeli presences on the landscape: the aftereffects of their weapons discharge, which he sardonically calls "AK-47 droppings" at the base on an olive tree. (In one memorable refiguring of these droppings, Palestinians in Bi'ilin plant flowers in the casings of spent tear gas canisters.)

Shehadeh's memoir also clearly denotes fear as a theme of walking while Palestinian: he reflects on how the pleasure of walking is undercut by the thought that one might be shot at (or by actually being shot at). This theme also permeates Macfarlane's $(2012,212)$ account of what he learned from Shehadeh as the two men walked together in the West Bank:

[Shehadeh] said that as a Palestinian it was inadvisable to walk outside the main cities, and that if you chose to do so it was inadvisable to carry a map, a camera, or a compass, in case you met an Israeli patrol, for all were items that would provoke suspicion, confiscation, and even detention.

So even the most banal cyborg accompaniments to walking can arouse suspicion if you are Palestinian or appear Palestinian. On one of my visits, a Palestinian teenager was shot dead at a checkpoint. The soldier claimed that he thought the earbuds of the youngster's cellphone actually doubled as a bomb trigger. ${ }^{5}$

Shehadeh's memoir is structured around a distinctly Palestinian genre of walking: the sarha. The word originally refers to letting livestock out to pasture in the morning, but it now refers to a human amble, one without a clear goal or destination (Shehadeh 2007, 2; Macfarlane 2012, 212), thereby bearing a stronger resemblance to a Situationist dérive than a stroll made by a Benjaminian flaneur. In a sarha, serendipitous encounters provide a valued event impossible to anticipate in advance. In contrast, in quantified walking, recording the number of steps one takes seems more important that what one might see. Shehadeh's sarha walking and his writing about walking become a way of showing paths of loss and reclamation for his readers, providing an inspiration to future walkers with the incorporation of mobility into his criticism of Israeli presence on the land (Sakhnini 2014).

Macfarlane $(2012,220)$ is but one of many discerning travelers to note that "travelers to the Holy Lands have always moved through a landscape of their imagination.” But Shehadeh's style of walking becomes a spiritual walk for the nonspiritual: those who resist the restriction of the Holy Land to biblical knowledge. In the early twentieth century, the shatha, or outing, was beloved by the Jerusalem middle class who would leave the city to breathe fresh air, pick flowers, enjoy nature, pic- 
nic, and duly photograph the event (Halaby 2015). The Shatha Group, started in 2006 by Saleh Abdel Jawad, a political scientist, and Salma Botmeh, an economist, envisioned it as a nature walking group, open to all. Key to the group is recording nature as a form of cultural heritage, exploring the paths of movement that are still possible for Palestinians to roam and ramble in. Setting out to walk along the Separation Wall, the British comedian Mark Thomas (2011) describes his interaction with Shatha Group walkers who view their walking endeavors as an effort to escape from the infrastructures of control. ${ }^{6}$ Shehadeh wrote a brief introduction to Walking Palestine: Twenty-Five Journeys into the West Bank, a guidebook by Stefan Szepesi (2012), while working with Tony Blair's Office of the Quartet on facilitating the now defunct peace process. The joint foreigners/Palestinians group he started, called Walking Palestine, now has considerably more than the initial two hundred members. The guidebook makes light references to biblical knowledge of the Holy Land (quipping, for instance, that Jesus didn't take the bus), but the walks therein acknowledge contemporary political realities by telling the reader how to avoid settlements, checkpoints, and army posts, all sites of potential conflict for Palestinian walkers. These walks and Shehadeh's sarhas signal the themes of reclamation through the embodied experience of Palestinians, in contrast to the intent of the hiking trips of the early Zionists (Benevisti 2000). Rebecca Stein (2009, 335) describes these nature walks (tiyulim) as strategic practices for inculcating Zionist interpretations of the landscape and, ultimately, colonial occupation.

By bringing the Jewish hiker into intimate contact with the homeland, such travelling practices were thought to foster a powerfully tactile sense of national awakening, affording the Jewish walker with firsthand knowledge of both land and homeland. In the terms of the broader Zionist pedagogy in which they played an important role, [nature walks] were deemed a crucial means of linking nature to nation, of connecting Jewish history . . to a set of Zionist political claims in the present, therein fortifying the latter.

Stein addresses the wider problem of Israeli settler colonialism: asserting an empty land waiting to be colonized, while having to acknowledge the presence of Palestinian Arab occupants whom the Jewish walkers encountered (Stein 2009, 337). ${ }^{7}$ Promoted here is an asserted textual Jewish past, erasing the living Palestinian present, a tendency Susan Slyomovics $(2014,44)$ finds in early Israeli art: "Thus settler art, much like colonial settlements, seizes land by making claims over the existence of actual native artifacts (e.g., Palestinian Arab vernacular architecture).” 
In contrast to Zionist walking, Shehadeh's walking and his writing about walking become a form of resistance to dispossession and a source of inspiration for a tactile way of knowing and contesting exclusion from the land. While the walks described in Shehadeh's book are individual or are conducted with a few friends, several kinds of recent Palestinian walks resemble the group-oriented walks of the Shatha Group. These represent efforts to ensure that Palestinian children, often reared in the city or in a refugee camp, come to know the land. I offer an example of one of these nature walks in which I participated in April 2017. I met the organizer at Dar Zahran, a small museum in a restored old Palestinian house in Ramallah's old town. It was a simple plan: a time on the weekend and a meeting place on the outskirts of Ramallah were provided to get interested Palestinians of all ages, including young children, out into the countryside to explore the landscape and learn about it. Ramallah locals were joined by a busload of people from Jenin and one from Bethlehem, which served the explicit purpose of uniting Palestinians from different parts of the West Bank. ${ }^{8}$ It proved an egalitarian affair: everyone brought their own lunches and some even brought sheeshas, while the organizers provided coffee made on a wood fire. We began our walk on the terraced olive land of Terra Fidea, outside of Ramallah. There were members of the Palestinian Wildlife Society and Mahmiyat, a Palestinian Authority initiative to actively protect and promote Palestine's nature reserves. A German-funded initiative called Hanns Seidel provided cameras for Palestinian youth to photograph the flora and fauna of the land. Dar Zahran's walkers also included amateur foragers, who impressed me with their ways of seeing. They managed to identify and harvest edible fruits from the landscape in ways that I and some of the Palestinian children could not, although I trustingly munched on the plants offered to me. Like the mushroom foragers described by Anna Tsing (2015), Palestinian foragers are reclaiming their land by teaching youngsters how to discover precious value in soil that can nurture them. In this context, walking becomes a healthful practice, but it is not recorded walking merely for one's own health. Instead, its purpose consists in sharing cultural knowledge about plants and trying to inculcate a sense of connection between persons and the land.

The manner of walking impressed me, too: the jumping, really, the racing up and down the hills, the skipping over the rough rocks and soil. Young men, middle-aged men with paunches and cigarettes, girls with modest ankle-length robes, women with children - all of them felt comfortable on the path and terraces that seemed to me more suitable for goats. We used to say "safety first!" but I described this as a "safety last!" approach to my Palestinian friend Baha, contrasting the ex- 
uberant Palestinian way of making a way through the landscape with my own perhaps unduly cautious, definitely inelegant exploration of the uneven ground. He snorted and said that Palestinians loved to show off: "Just give them a chance and they will jump around like goats." Returning to Shehadeh's (2007, 2) description of the Palestinian love for the sarha, we see how he describes the giddiness that I sensed in my Dar Zahran walk: "Going on a sarha implies letting go. It is a drug-free high, Palestinian-style," away from the checkpoints, constraints, Wall, towers, and speeding settlers who pay little heed to Palestinian pedestrians. Shehadeh (2007, 142) also describes a walk he took with the anthropologist Rema Hammami:

As soon as we left the taxi that brought us down close to Wadi Qelt we found ourselves almost running over the hills, which were like a brown tapestry. We felt euphoric. Being stuck in Ramallah, surrounded as it was with checkpoints at every exit, the experience of open space, with no walls, no barriers and a wide open sky, made us giddy with joy.

\section{$* * *$}

Another version of the sarha is the notion of outing (mishwar) that is today spun into "MishArt": artistic walking-outings. These walks are put on by a network of artists and activists, foreign and Palestinian, who are involved in supporting contemporary art and architecture revivals in the Beit Sahour-Bethlehem area. Participants engage in a walk to visit local artists' studios, highlighting long artistic and architectural traditions and ongoing creativity. Participants are shown these reclamation activities by local artists who go beyond producing religious tourist art for the centuries-old pilgrim market in this part of the Holy Land. We walked from studio to studio, adding a kinesthetic dimension to these attempts to regenerate Palestinian art. The MishArt in which I participated included the studio of the musician Aref Sayed, housed in a beautifully renovated example of old Palestinian vernacular architecture, where he both makes and repairs ouds, beautiful instruments famed in many Middle Eastern music traditions. From there we walked to the Latin Church for a concert by Palestinian children's choirs, sponsored in part by the Said/Barenboim Foundation. In October 2018, I participated in another kinesthetic tour called "Wandering in Flavors," which visited distinctive food spots in the Old City of Jerusalem, like the vanishing tahini factories and bakeries. ${ }^{9}$

Similarly, reclaiming Palestinian vernacular architecture from the imperial/ occupation ruins is the central project of the Riwaq Center for Architectural Con- 
servation, a longstanding Palestinian NGO headed by the architect and author Suad Amiry. But what interests me here is Riwaq's ("re-walk" in English) introduction of walking tours to sites of renovation or future sites:

The Ramallah Highlands Trail represents the mutual heritage of sites within the wider scheme of the most significant fifty historic centers across the region as identified by Riwaq. The trail examines and promotes Palestinian cultural heritage highlighting nineteenth- and twentieth-century architectural heritage, the surrounding cultural landscape, and archeological sites.

Riwaq has recently organized walks to Lifta, a profoundly moving ruin, one of the few Palestinian villages left standing within the Israeli side of the 1949 armistice line, if in an eerie, decaying, and depopulated state.

\section{CONCLUDING MEANDERINGS}

The proliferation of movement and concern for it still leaves aside a basic fact about walking while Palestinian, one, as Tawil-Souri (2011) notes, that hinges on a technology more primitive than the Fitbit: the ID card and the permit. Access to Lifta is itself limited to Palestinians with permits to Jerusalem, which are becoming increasingly rare and hard to acquire. So for many West Bank Palestinians, the walks that I performed as a foreigner with a Canadian passport would be not possible at all. If one cannot get into Jerusalem, one cannot walk, as I did on the walls of the Old City; those Palestinians who do have access to Jerusalem refuse to pay the Israeli tourism board $\mathrm{D} 18$ to ascend the walls of their own city. Sometimes the way people walk in Palestine is not a matter of their own choice. In October 2018, we were picking olives on land that had been rezoned as part of Jerusalem. Our guide did not have permission to enter Jerusalem, so he could not come on the bus with the foreign volunteer olive pickers, lest the Palestinian bus driver get fined or even arrested. As our guide had to walk down the terraces to access the land on which we were picking, a few of us came with him, to recast his exclusion into a bit of a sarha. The sun came out after the rain and despite slipping on mud, there were lots of laughs about the clumsiness of those who were unaccustomed to descending terraces (including the anthropologist who was still recording her steps). We felt triumphant when we made it to our picking spot before those who had been comfortably transported by bus. Our playful subversion had attempted to repress the eerie feeling that more exclusions were in the offing. 
The above are facts that your Fitbit cannot tell you. While I began with the Fitbit in keeping with how it is marketed, as a device for self-surveillance with the goal of healthy self-improvement, I certainly do not wish to claim a vulgar technological determinism that holds true in all times and places. The Fitbit and similar technologies can undoubtedly be used in more creative fashions, and potentially for a common good. ${ }^{10}$ This essay offers less a thick description of Palestinian walking than a reflection on how we can use a universal technique of the body, in its Fitbit cyborgian incarnation and with its piety of inculcating health and responsible citizenship, as an ethnomethodological opportunity. How can quotidian practices such as walking and self-surveillance be understood in contexts where a much more charged and dangerous relationship exists between the surveillance of the self and that of the other? While I had no intention of doing anything more than continuing my walking competition with my father, the practice itself provided a serendipitous path to talking about walking, especially to those who found quantified walking absurd. Although Palestinians can indulge in playful competition consisting of jumping across the landscape like goats, the Fitbit style of play and its corollary body-as-pet seem excessive to many. At least it seemed that way in 2017. ${ }^{11}$ One of my interlocutors, a Palestinian bookshop owner in East Jerusalem, expressed enormous relief at my writing an article about the Fitbit, as that seemed to give the activity a certain goal (and dignity!) that he could respect. In many ways, I agree with him completely: I would never feel compelled to count my steps, to record them religiously, just to compete with myself or strangers without joking with my father or analyzing the process anthropologically. But as I described to my interlocutors how our familial Fitbit competition ended up as a form of loving kinwork, a daily e-phatic communication that allowed us, after a fashion, to walk together despite the thousands of miles between us, my Palestinian friends were moved. As members of a people who have become emblematic of continued displacement, they have all experienced the challenges of doing creative, connective kinwork across a distance. Kinwork and academic work make the self-surveillance meaningful to me, although this form of work pales in contrast to the enormous self-work required to prevent the other-surveillance regime's reach into the soul. In the abstract, nothing makes the sarha or shatha inherently incompatible with a Fitbit, although there are a few obvious reasons why the act of measuring one's steps as an end unto itself might have its limits as a primary concern. In terms of the mental energy devoted to movement, DTSD recording activity has nothing on Palestinians' extraordinary mental capacity to figure out alternative routes in the everyday due to closures and reroutings of movement both expected and unexpected. As Hammami $(2015,12)$ 
points out, "the refusal to be made abject by that suffering is what marks you as a member of this particular moral community."

Walking seems to be one of those ways in which Palestinians are refusing to be made abject, refusing, as far as they can, negative stasis while engaging in positive stasis. The proliferation of organized group walking, or of friends out for a stroll, was something Palestinian friends have remarked on in recent years. At this historical moment of serious constraint, walking constitutes a tactic through which Palestinians not only resist dispossession and appreciate the beauty and richness of their land but also transform and contest the dominant depictions of Palestinian life as merely bare life, one devoid of the joys, hopes, laughter, creativity, and energy that also mark daily life in Palestine.

\title{
POSTSCRIPT
}

After I finished my final revisions to this essay, I decided to go for an early morning walk to Al Haram Al Sharif, the remarkable complex that contains the Dome of the Rock and Al Aqsa mosque. My entry, via the Israeli checkpoint outside the complex, was facilitated by my Canadian passport and my response of "Catholic" to the Israeli soldier's question about my religion. (My usual self-description as a "fallen Catholic" or "godless anthropologist" seemed a little too nuanced for checkpoint interaction with a young, armed soldier.) My Palestinian interlocutors were amused to hear that somewhere between the beautiful golden dome and the olive groves that face it, I lost my Fitbit, which seemed a timely end.

\begin{abstract}
This essay examines how meanings and practices of walking, particularly quantified walking, change according to place. Drawing together my own experience with a wearable computing device called a Fitbit at home and in my field site, East Jerusalem and the occupied West Bank of Palestine, I compare quantified walking and its focus on the self with other forms of walking that highlight place. I examine the relationship between self-monitoring and other-monitoring, especially in relation to walking in Palestine, and I explore how genres of mobility like nature walking or playing Pokémon GO might unfold differently in an occupied territory where the right to move is highly contested. I also explore Palestinian genres of walking, including the wander (sarha). In Palestine, walking becomes an important means not for pursuing personal health, but for cultivating a wider health of the land and knowledge of the nurturing relationship between land and the people who walk across it. Such practices of walking with or walking together can, I conclude, function as forms of kinwork. [walking; quantification; self-monitoring; surveillance; kinwork]
\end{abstract}


خلاصة

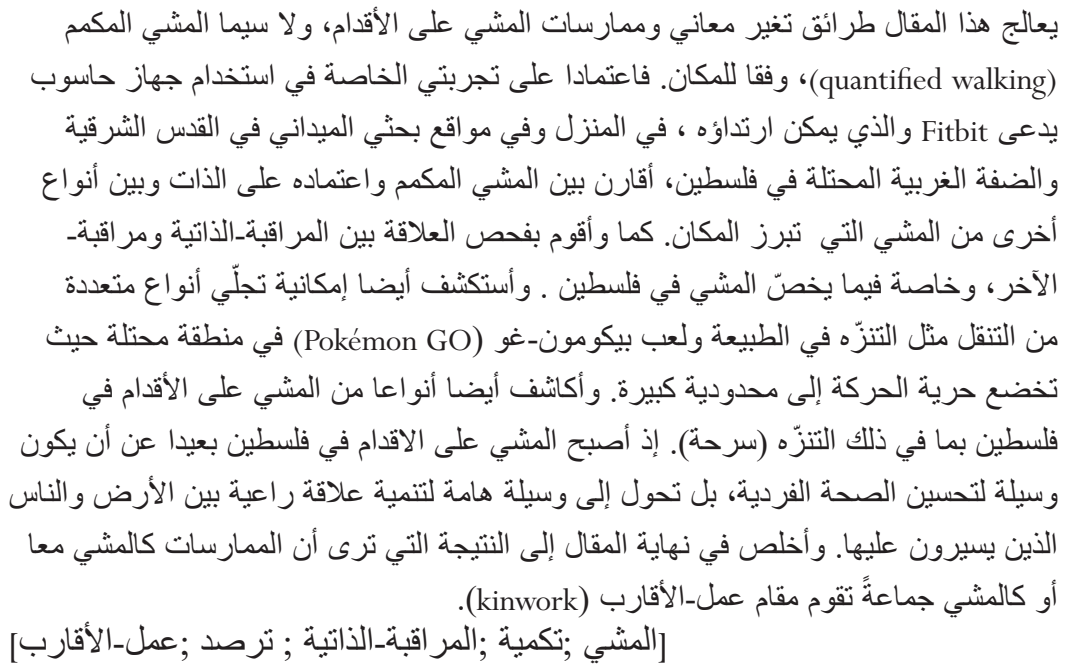

\section{NOTES}

Acknowledgments It was an oddly timely gift to be the token anthropologist among people who identify as writers for the "The Art of Walking" workshop at the Banff School of the Arts and Creativity in April 2018, especially since the last time I was in Banff, I was a child, walking with my father, Bob Meneley. This essay is dedicated to him and to the memory of someone dear to both of us, Katherine Lesack, herself a great walker. I greatly appreciated the inspiration of my writing mentors at Banff, Garnette Cadogan and Anna Badkhen. I am grateful for the insights of the beautiful and brilliant Rema Hammami and Rana Barakat, and, closer to home, for those of Bruce Grant and Paul Manning. Vaidila Banelis continues to make quotidian life more fun. For various inspirations, both intended and unintended, I thank Ken Albala, Mirna Bamieh, Theo Banelis, Kate Dougherty, Daoud Ghoul, Baha Hilo, Aisha Mansour, Imad Muna, Marie Paterson, Alejandro Paz, Brennan Sekulic, and Vivien Sansour. For invitations to present versions of this essay, thanks go to Mustafa Koç and Ingrid Hehmeyer of Ryerson University and Nefissa Naguib of the University of Oslo. This research was funded by the Social Sciences and Humanities Research Council of Canada. Thanks to the editors of Cultural Anthropology, especially Christopher Nelson, and to the thoughtful reviewers they chose for this piece.

1. "Strava or it didn't happen" is a saying that captures the impetus to record. The product's website notes that "strava is the Swedish word for 'strive,' which epitomizes who we are and what we do: If you're striving to improve, no matter your goals or ability, you're one of us."

2. See also Lalah Khalili's (2010) important discussion about the centrality of Palestine as a place for developing surveillance and counterinsurgency strategies for the British and the Israelis.

3. Although East Jerusalem technically forms part of the West Bank, the Israelis ultimately control access to it, which creates a constant source of tension. Palestinians with West Bank ID or Gaza ID can only gain access to Jerusalem if they have special permits. All official documents are ultimately issued by Israel. For a nuanced discussion of the complicated system of permits, see Tawil-Souri 2011 and Berda 2018.

4. Underpinning this initiative is the questionable assertion that the supposedly universal desire of women to lose weight and talk about it will provide an opportunity to unify Israeli and Palestinian women. 
5. Although I distinctly remember the panicked schoolchildren ripping their earbuds out at Qalandiya checkpoint the next day, I do not remember the child's name, much as his senseless death deserves recognition.

6. As Penny Johnson $(2011,102)$ points out in her review of Thomas's book, it draws attention to the current constriction of Palestinians' "right to ramble." The Shatha Group also appears in an article titled "Rambling in Palestine" by the British Mountaineering Council's Carey Davies (2014).

7. Zachary Lockman (1996, 29-38) makes the point that the well-known Zionist slogan "land without a people for a people without a land" does not mean that the early Zionists didn't realize Arabs lived on the land, but rather that they did not consider the Arabs there as a people that could constitute the land as a nation. Similarly, the continuing presence of Palestinians often seems to create the same effect: in a move that differs from complete erasure, contemporary settlers see them without recognizing them as legitimate landholders with rights. My thanks to Alejandro Paz for our conversations on this topic.

8. One of the reviewers for this article suggested that this might constitute a third kind of piety, a nationalist one. While my consultants were leery of associating with the explicit nationalist talk of the Palestinian Authority, they certainly supported the idea of getting to know the land of the country for urban Palestinians. But we could see walking together as work attempting to unite Palestinians from different parts of the West Bank and East Jerusalem as analogous to the walking kinwork that I do with my father and the Fitbit. Some even try to connect, when possible, Palestinians who are living in Israel with those in the West Bank.

9. This tour formed part of the Palestine Hosting Society's live art project, sponsored by AlMa'mal Foundation for Contemporary Art.

10. Scholars of the wider field of biosensing (beyond Fitbit) have explored the capacity for self-tracking tools to generate data potentially for a collective good: see Taylor 2016 on envisioning better bike routes and Bohlen 2016 on managing water contaminations. See also Greenfield 2016 for a moving account of how her dying mother's data got drawn into another form of caring kinwork.

11. Those Palestinians who might be inclined to self-tracking in ways familiar to North Americans failed to see why one would invest in the added expense of a Fitbit when one can use a phone app should one be so inclined. During my visit in October 2018, I was told of some young men and women who do compete in this way.

\section{REFERENCES}

Abu-Lughod, Lila

2007 "The Return to Half-Ruins: Memory, Postmemory, and Living History in Palestine." In Nakba: Palestine, 1948, and the Claims of Memory, edited by Ahmad H. Sa'di and Lila Abu-Lughod, 76-104. New York: Columbia University Press.

Allen, Lori

2008 "Getting by the Occupation: How Violence Became Normal During the Second Palestinian Intifada." Cultural Anthropology 23, no. 3: 453-87. https://doi.

Amiry, Suad org/10.1111/j.1548-1360.2008.00015.x.

Arland-Fye, Barb

2010 Nothing to Lose But Your Life. Doha: Bloomsbury Qatar Publishing.

2016 "Persons, Places, and Things: Every Step You Take." Catholic Messenger, June 9. https:/ / www.catholicmessenger.net/2016/06/persons-places-and-things-every-

Benevisti, Meron step-you-take.

2000 Sacred Landscape:The Buried History of the Holy Land since 1948. Berkeley: University of California Press. 
Benjamin, Walter

2003 Charles Baudelaire: A Lyric Poet in the Era of High Capitalism. Translated by Harry Zohn. New York: Verso. Originally published in 1973.

Berda, Yael

2018 Living Emergency: Israel's Permit Regime in the Occupied West Bank. Stanford, Calif.: Stanford University Press.

Bier, Jess

2017 "Palestinian State Maps and Imperial Technologies of Staying Put." Public Culture 29, no. 1: 53-78. https://doi.org/10.1215/08992363-3644397.

Bishara, Amahl

2015 "Driving while Palestinian in Israel and theWest Bank:The Politics of Disorientation and the Routes of Subaltern Knowledge." American Ethnologist 42, no. 1: 33-54.

Bohlen, Marc https://doi.org/10.1111/amet.12114.

2016 "Field Notes in Communication Studies." In Quantified: Biosensing Technologies in Everyday Life, edited by Dawn Nafus, 169-88. Cambridge, Mass.: MIT Press.

Cadogan, Garnette

2016 "Walking while Black." Literary Hub, July 8. https://lithub.com/walking-whileblack.

Cohen, Yinon, and Neve Gordon

2018 “Israel's Biospatial Politics: Territory, Demography, and Effective Control." Public Culture 30, no. 2: 199-220. https:// doi.org/10.1215/08992363-4310888.

Cristiano, Fabio, and Emilio Distretti

2017 "Along the Lines of the Occupation: Playing at Diminished Reality in East Jerusalem." Conflict and Society 3, no. 1: 130-43. https://doi.org/10.3167/arcs.2017.030111.

Davies, Carey

2014 "Rambling in Palestine." Great Outdoors, June.

Ehrenreich, Barbara

2018 Natural Causes: An Epidemic of Wellness, the Certainty of Dying, and Killing Ourselves to Live Longer. New York: Grand Central.

Gershon, Ilana

2016 “'I'm not a businessman, I'm a business, man': Typing the Neoliberal Self into a Branded Existence." HAU 6, no. 3: 223-46. https://doi.org/10.14318/hau6.3.017.

Greenfield, Dana

2016 "Deep Data: Notes on the n of 1." In Quantified: Biosensing Technologies in Everyday

Halaby, Mona Hajjar Life, edited by Dawn Nafus, 123-46. Cambridge, Mass.: MIT Press.

2015 "The Proverbial Shatha in Early Twentieth-Century Jerusalem." Jerusalem Quarterly, Hammami, Rema no. 61: 69-83. https://www.palestine-studies.org/jq/fulltext/190766.

2004 "On the Importance of Thugs: The Moral Economy of a Checkpoint." Middle East Report, no. 231: 26-34. https://www.merip.org/mer/mer231/importance-thugs.

2010 "Qalandia: Jerusalem's Tora Bora and the Frontiers of Global Inequality." Jerusalem Quarterly, no. 41: 29-51. https://palestine-studies.org/jq/fulltext/78348.

2015 "On (Not) Suffering at the Checkpoint: Palestinian Narrative Strategies of Surviving Israel's Carceral Geography." borderlands e-journal 14, no. 1. http://www. borderlands.net.au/issues/vol14no1.html.

2018 "Destabilizing Mastery and the Machine: Palestinian Agency and Gendered Embodiment at Israeli Military Checkpoints." Current Anthropology, October 29. https://doi.org/10.1086/699906.

Hern, Alex

2018 "Fitness Tracking App Strava Gives Away the Location of Secret U.S. Army Bases." Guardian, January 28. https://www.theguardian.com/world/2018/jan/28/ fitness-tracking-app-gives-away-location-of-secret-us-army-bases. 
Ito, Mizuko, Daisuke Okabe, and Misa Matsuda, eds.

2005 Personal, Portable, Pedestrian: Mobile Phones in Japanese Life. Cambridge, Mass.: MIT Press.

Johnson, Penny

2011 "Have You Heard the One about the Wall? Book Review of Extreme Rambling." Jerusalem Quarterly, no. 47: 98-102. https://www.palestine-studies.org/jq/ fulltext/78446.

Khalili, Laleh

2010 "The Location of Palestine in Global Counterinsurgencies." International Journal of Middle East Studies 42, no. 3: 413-33. https://doi.org/10.1017/ S0020743810000425.

Lockman, Zachary

1996 Comrades and Enemies: Arab and Jewish Workers in Palestine, 1906-1948. Berkeley: University of California Press.

Lupton, Deborah

2016 The Quantified Self. Malden, Mass.: Polity.

Macfarlane, Robert

2012 The OldWays: A Journey on Foot. New York: Penguin.

Mauss, Marcel

1973 "Techniques of the Body." Translated by Ben Brewster. Economy and Society 2, no. 1: 70-88. Originally published in 1935. https://doi.org/10.1080/ 03085147300000003 .

Meneley, Anne

2014 “The Accidental Pilgrims: Olive Pickers in Palestine.” Religion and Society 5, no. 1: 186-99. https://doi.org/10.3167/arrs.2014.050112.

2016 "Checking Your Waistline at the Checkpoint: Dieting as a Peace Initiative." Jerusalem Quarterly, no. 68: 90-103. https://www.palestine-studies.org/jq/issue/68.

Moore, Phoebe, and Andrew Robinson

2016 "The Quantified Self: What Counts in the Neoliberal Workplace." New Media and Society 18, no. 11: 2774-92. https://doi.org/10.1177/1461444815604328.

Nafus, Dawn

2016 "Introduction." In Quantified: Biosensing Technologies in Everyday Life, edited by Dawn Nafus, ix-xxxi. Cambridge, Mass.: MIT Press.

Neff, Gina, and Dawn Nafus

2016 Self-Tracking. Cambridge, Mass.: MIT Press.

Paz, Alejandro I.

2014 "Guiding Settler Jerusalem: Voice and the Transpositions of History in Religious Zionist Pilgrimage." Religion and Society 5, no. 1:128-42.https://doi.org/10.3167/ arrs.2014.050108.

Peteet, Julie

2017 Space and Mobility in Palestine. Bloomington: Indiana University Press.

Pink, Sarah, and Vaike Fors

2017 "Being in a Mediated World: Self-Tracking and the Mind-Body-Environment." cultural geographies 24, no. 3: 375-88. https://doi.org/10.1177/ 1474474016684127.

Ruckenstein, Minna, and Natasha Dow Schüll

2017 "The Datafication of Health." Annual Review of Anthropology 46: 261-78. https:// doi.org/10.1146/annurev-anthro-102116-041244.

Ryave, Lincoln A., and James N. Schenken

1974 "Notes on the Art of Walking." In Ethnomethodology: Selected Readings, edited by Roy Turner, 265-78. Harmondsworth, UK: Penguin Education.

Sakhnini, Mohammad

2014 "Walking, Telling, Resisting in Raja Shehadeh's Palestinian Walks." Settler Colonial Studies 4, no. 2: 209-219. https://doi.org/10.1080/2201473X.2013.819064. 
Sanders, Rachel

2017 "Self-Tracking in the Digital Era: Biopower, Patriarchy, and the New Biometric Body Projects." Body and Society 23, no. 1: 36-63. https://doi. Schüll, Natasha Dow org/10.1177/1357034X16660366.

2017 “Our Metrics, Ourselves.” Public Books, January 26. http:/ /www.publicbooks.org/ our-metrics-ourselves.

Sedaris, David

2014 “Stepping Out: Living the Fitbit Life." New Yorker, June 30. http:/ / www.newyorker. com/magazine/2014/06/30/stepping-out-3.

Shalhoub-Kervorkian, Nadera

2016 "Clowns in Palestine Cry: The Occupied Bodies and Lives of Jerusalem's Children." Journal of Palestine Studies 45, no. 2. https://www.palestine-studies.org/jps/ fulltext/198544.

Shehadeh, Raja

2007 Palestinian Walks: Notes on a Vanishing Landscape. London: Profile Books.

Sherman, Jamie

2016 "Data in the Age of Digital Reproduction: Reading the Quantified Self Through Walter Benjamin.” In Quantified: Biosensing Technologies in Everyday Life, edited by Dawn Nafus, 27-42. Cambridge, Mass.: MIT Press.

Sicart, Miguel

2014 "Playing the Good Life: Gamification and Ethics." In The Gameful World: Approaches, Issues, Applications, edited by Steffen P. Walz and Sebastian Deterding, 225-44. Cambridge, Mass.: MIT Press.

Slyomovics, Susan

2014 "Who and What is Native to Israel? On Marco Janco's Settler Art and Jacqueline Shohet Kahanoff's 'Levantinism.”' Settler Colonial Studies 4, no. 1: 27-47. https://

Solnit, Rebecca doi.org/10.1080/2201473X.2013.784238.

2000 Wanderlust: A History of Walking. New York: Penguin.

Stein, Rebecca L.

2009 “Traveling Zion: Hiking and Settler Nationalism in Pre-1948 Palestine.” Interventions 11, no. 3: 334 -51. https://doi.org/10.1080/13698010903255569.

Szepesi, Stefan

2012 Walking Palestine: Twenty-Five Journeys into the West Bank. Northampton, Mass.: Interlink Books.

Tawil-Souri, Helga

2010 "Qalandia Checkpoint: The Historical Geography of a Non-Place." Jerusalem Quarterly, no. 42: 26-48. https://www.palestine-studies.org/jq/fulltext/78360.

2011 "Colored Identity: The Politics and Materiality of ID Cards in Palestine/Israel." Social Text 29, no. 2: 67-97. https:/ / doi.org/10.1215/01642472-1259488.

2016 "Surveillance Sublime: The Security State in Jerusalem.” Jerusalem Quarterly, no. 68: 56-65. https://www.palestine-studies.org/jq/fulltext/210944.

2017 “Checkpoint Time." Qui Parle 26, no. 2: 383-422. https://doi.org/10.1215/ 10418385-4208442.

Taylor, Alex

2016 "Data, (Bio)Sensing, and (Other-)Worldly Stories from the Cycle Routes of London." In Quantified:Biosensing Technologies in Everyday Life, edited by Dawn Nafus, Thomas, Mark 189-209. Cambridge, Mass.: MIT Press.

2011 Extreme Rambling:Walking Israel's Separation Barrier. For Fun. London: Ebury Press.

Tsing, Anna Lowenhaupt

2015 The Mushroom at the End of the World: On the Possibility of Life in Capitalist Ruins. Princeton, N.J.: Princeton University Press. 
Urciuoli, Bonnie

2008 "Skills and Selves in the New Workplace." American Ethnologist 35, no. 2: 211-28.

Weizman, Eyal https://doi.org/10.1111/j.1548-1425.2008.00031.x.

2007 Hollow Land: Israel's Architecture of Occupation. New York: Verso.

Whitson, Jennifer

2014 "Foucault's Fitbit: Governance and Gamification." In The Gameful World: Approaches, Issues, Applications, edited by Steffen P. Walz and Sebastian Deterding, 339-58. Cambridge, Mass.: MIT Press. 